\title{
Availability of books as a factor in reading, teaching and learning behaviour in twenty disadvantaged primary schools in South Africa
}

\author{
Mary Nassimbeni \\ Centre for Information Literacy, University of Cape Town \\ Mary.nassimbeni@uct.ac.za \\ Snoeks Desmond ${ }^{2}$ \\ Snoeks@global.co.za
}

Received 10 September 2011

Accepted 15 September 2011

\begin{abstract}
The purpose of the research project was to investigate the effects of the provision of story books in twenty disadvantaged primary schools in rural South Africa. The recipients of the donation were children in deprived areas, growing up in printpoor environments. The programme theory of the donor organisation, Biblionef, is that access to attractive ageappropriate books will have beneficial effects such as improved literacy skills, the promotion of confidence and improvement in learning. A qualitative approach was adopted to collect data before the intervention, and six months after the book donation, which included a comprehensive training programme in the use of the books. During the site visits, observation schedules were used; also focus groups of both teachers and children. We were able to chart impact in a number of areas such as improved availability and use of books in fifteen of the schools, with respect to both classroom activities and voluntary reading. In five schools there was no appreciable change. We recommend that innovation in teaching approaches associated with the use of books should be accompanied by careful training, and benign monitoring.
\end{abstract}

Keywords: Books, disadvantaged schools, reading, teaching and learning behaviour, South Africa

\section{Introduction}

The purpose of the research project was to investigate the effects of the provision of story books in twenty disadvantaged primary schools in rural South Africa. The recipients of the donation were children in deprived areas, growing up in printpoor environments, and attending under-resourced schools. South Africa's education system is in crisis and the President has pledged his government's commitment to placing education at the centre of the government's programme, and to raising reading levels at school (South Africa, Department of Basic Education 2010).

The dramatic language used by the Department of Education (DBE) to report on the reading levels in South African schools ('shockingly low', 'disastrously poor', 'crisis in education', 'shocked the nation'3) reflects their concern that South African learners are performing at lower levels than their global counterparts, even in other African countries which spend less on education, and which are less well resourced (South Africa, Department of Basic Education 20I0). Government spending on education takes the largest slice of the budget, about $20 \%$, a figure that grows annually. In 2008/2009 the figure was RI40 billion; in 2010/20II it will be RI65 billion. The education spend of 5.4\% of GDP far exceeds that of any other African country (Jansen 20I I: 15). The most recent confirmation of "unacceptable" low levels of reading performance in South African school system were published on 28 June $201 \mathrm{I}$, when the Minister of Education released the results of the first ever national test of literacy and numeracy of 6 million children from Grades 2 to 7 in all public schools in the Annual National Assessment (Motshekga 201I). The results of the Annual National Assessment (ANA) showed that Grade 3 pupils scored an average of $35 \%$ for literacy and $28 \%$ for numeracy. In Grade 6 the national average for literacy was $28 \%$ and for numeracy $30 \%$. The level of children's literacy is clearly associated with adult illiteracy; UNESCO's figures place South Africa 108 out of 178 countries for literacy (Mohlala 20I I).

While the ANA results were shocking, they confirmed the results of international tests such as the Progress in International Literacy Study (PIRLS) 2006 where South Africa achieved the lowest score of 40 countries and 45 education systems $^{4}$ (Howie et al., 2008). The pupils from schools where books and libraries are available scored better than those at schools without these resources, viz. 363 for the former group as compared to 262 for the other group, emphasising the link between disadvantage and poor performance. This correlation is confirmed by Van der Berg et al., (20lI) who

I. Mary Nassimbeni (PhD), principal author, is a lecturer in the Centre for Information Literacy, University of Cape Town.

2. Snoeks Desmond $(\mathrm{PhD})$ is an independent researcher in the field of literacy studies in South Africa.

3. For example, see the comments of Angie Motshekga, Minister of Basic Education, reported in the Cape Times of 27 June 201 I.

4. The Russian Federation had the highest scores; the Unesco survey of 1999 showed that the Russian Federation had the highest book borrowing from public libraries (UNESCO 1999)

MacFarlane has pointed out that in spite of rapid urbanisation, most South African pupils attend schools in rural areas (2005:4). 
report that the richest $20 \%$ of pupils in Grade 6 scored 605 for reading, in comparison to a score of 436 for the poorest participants in a test carried out by the Southern and Eastern African Consortium for Monitoring Education Quality (SACMEQ II) in 2007 (Van der Berg et al., 201 I: 3).

\section{Children's access to reading materials: school libraries in South Africa}

The South African government's National Reading Strategy of 2008, attempting to remedy the problem, identified six focus areas requiring attention:

- Teacher competency;

- Libraries;

- Teaching conditions;

- Print environment;

- Language issues; and

- Inclusive education (South Africa. Department of Education 2008: 8-10).

In spite of the apparent commitment of DBE to libraries, the state of school libraries in South Africa, and therefore the provision of suitable reading material, is a source of great concern to the LIS sector. Recognising their singular neglect and decline, the Transformation Charter devotes "much more comprehensive and detailed analysis" to the topic than to other sections, thus highlighting their special challenges (The Library and Information Services Transformation Charter. 2009: viii). The Library and Information Services Transformation Charter is a document commissioned by Government with the brief to:

- 'Define the challenges facing the sector

- Provide a clear framework of principles and mechanisms for effecting the changes needed for the sector to contribute to the elimination of illiteracy and inequality and build an informed and reading nation' (The Library and Information Services Transformation Charter 2009: vii).

The Charter points out the special role that libraries play in developing reading literacy and laments their "virtual nonexistence" (2009: 39-40), a situation which has been documented by Equal Education, a non-governmental organisation (NGO) in Cape Town, as shown in Table I.

Table I School libraries in South Africa

\begin{tabular}{|c|c|c|c|c|c|}
\hline Province & No of schools & $\begin{array}{l}\text { (A) Schools with no } \\
\text { library space, no } \\
\text { materials, librarian }\end{array}$ & $\begin{array}{l}\text { (B) Schools with space } \\
\text { but no materials, } \\
\text { librarian }\end{array}$ & $\begin{array}{c}\text { (A) }+(B) \text { Schools with } \\
\text { no materials and no } \\
\text { librarian }\end{array}$ & $\begin{array}{l}\text { Schools with functional } \\
\text { libraries }\end{array}$ \\
\hline Eastern Cape & 5669 & 5123 & 379 & 5502 & 167 \\
\hline Free State & $|53|$ & 1138 & 253 & 1390 & $14 \mid$ \\
\hline Gauteng & 1970 & 810 & 787 & 1598 & 372 \\
\hline KwaZulu-Natal & 5928 & 4710 & 848 & 5558 & 370 \\
\hline Limpopo & 4035 & 3740 & 198 & 3938 & 97 \\
\hline Mpumalanga & 1844 & 1493 & 216 & 1709 & 135 \\
\hline Northern Cape & 600 & 483 & 177 & 561 & 39 \\
\hline North West & 1716 & 12099 & 304 & 1513 & 203 \\
\hline Western Cape & 1453 & 684 & 390 & 1073 & 380 \\
\hline Total & 24699 & 19344 & $347 I$ & 22796 & 1903 \\
\hline Percentage & 100 & 78.32 & 13.97 & 92.29 & 7.71 \\
\hline
\end{tabular}

Source: Equal Education (201 I: 23).

This situation is exacerbated by the fact that $85 \%$ of the South African population lives beyond the reach of a public library (South African Partners 2006). Townships, resettlement and rural areas have hardly any library resources, since public libraries are still predominantly situated in the formerly advantaged areas.

\section{The 60 schools project}

Biblionef is a book donation organisation registered as a Non-Profit making Company (NPC). In South Africa, Biblionef provides books to beneficiaries in the child's local language, which could be any of the eleven official South African languages. Biblionef's main aim is to make these books available in order for children to have access to books to create the love of reading. Its programme theory is that access and use of attractive age-appropriate books will have beneficial effects such as better literacy skills, the promotion of confidence and improvement in learning. It works through civil 
society organisations and government departments to ensure that the books reach those most in need of reading material in the language most relevant to the children.

Biblionef received a National Lottery grant to make book donations to 60 poorly resourced schools in four provinces; fifteen schools each in Eastern Cape, Gauteng, KwaZulu-Natal and Limpopo. Each school was given 300 books - 40\% in English, and $60 \%$ in the mother tongue of the school; half the donation being added by Biblionef. The provincial department of education in each province was responsible for the selection of beneficiary schools based on the severity of need, and logistics associated with the delivery of books; and also the appointment of a coordinator to oversee the project in each province. The impact study was undertaken in 20 of these schools randomly selected by each provincial coordinator. The majority of these schools were in rural areas, and three were in informal settlements. The investigation was conducted in Grade 4 as this is the transition year between instruction in mother tongue (at our sites, African languages) and instruction in English, a $2^{\text {nd }}$ or $3^{\text {rd }}$ language for the children and teachers at our sites.

The main purpose of this study was to observe and assess the impact of the donation of books and the handover training sessions, as a follow-up to a pilot project in four rural primary schools which showed disappointing use of the books. The pilot study attributed the low impact of the donated books in these very poor schools to insufficient training of teachers and principals in the value and use of books for voluntary reading. In the larger study (the subject of this paper) the book donation was accompanied in each case by extensive training of the class teachers receiving the books, based on principles derived from the pilot. The training covered the following topics:

- The benefits of reading, for pleasure and for information;

- Display of books;

- How to promote and manage the borrowing of books by children;

- Ways of reading with children for enjoyment, including speculating, dramatising, drawing; and

- Ways to improve fluency and comprehension, e.g. paired reading, silent reading.

\section{Framing the study}

The conceptualisation of childhood literacy influences the approach to research in this area, so an understanding of the terrain was important for us in order to frame the study. Two dominant approaches to an understanding of children's literacy can be identified. Many studies focus on the technology of reading, trying to measure progress in skills using preand post-tests involving, for example, assessment of comprehension. This approach has been driven by the planning need for interventions relying on hard comparative figures, and is manifested in many studies. These studies, important as they are, do not assist in understanding why some children read easily, and others do not (Comber and Cormack 1997: 22), or why some children choose to read and others do not. Researchers have begun to realise the value of investigating how literacy is used in different environments and the behaviour and patterns associated with reading in these conditions. The shift from the technology of reading towards a sociological approach has highlighted the following insights:

- "Literacy can be understood as socially and culturally constructed practices

- Literate competence is about cultural display (what is seen as 'good work' or successful performance in a classroom or centre are culturally preferred ways of talking, listening and behaving)

-When children come to school or kindergarten, they have to work out what counts as literacy in that context" (Comber and Cormack 1997: 22)

The PIRLS study defined reading literacy as "the ability to understand and use those written language forms required by society and/or valued by the individual. Young readers can construct meaning from a variety of texts. They read to learn, to participate in communities of readers in school and everyday life, and for enjoyment" (Mullis et al., 2009). This is a useful definition, highlighting as it does the reader's active construction of meaning, and pointing to its benefits. It is useful to consider what a literate person (or child) should be able to do:

- "Read and write with confidence, fluency and understanding

- Be interested in books, read with enjoyment and evaluate and justify their preferences

- Know and understand a range of genres

- Understand and be able to use a range of non-fiction texts ...

- Have an interest in words and word meanings, and a growing vocabulary” (Wray et al., 2002: 2).

The shift from a reading and comprehension skills focus to a greater concern with the social and cultural environment has been accompanied by the development of terminology to capture the complexity arising from the new understandings. The newly coined term "literacy event ... a label for the situations where one or more people are engaged in an activity which involves print" (Comber \& Cormack 1997: 24) suggested fruitful lines of inquiry in an investigation for which tests of reading and comprehension did not match its purpose. Our study of the literature surfaced a number of factors 
associated with the key concept 'literacy event', defined by Heath (1987: 93) as "any occasion in which a piece of writing is integral to the nature of participants' interactions and their interpretive processes". As Barton and Hamilton (2000: 8) point out, they are "observable episodes which arise from practices and are shaped by them". Our experience in the pilot project isolated the following factors associated with literacy events, each of which is amplified below:

- Availability of books;

- Voluntary reading: reading for pleasure; and

- Reading in the mother tongue.

4.1 Availability of books

A study of investigations in similar situations has shown that the significance of the concept 'access' or 'availability' for reading is considerable. Krashen (2004) has noted the relationship between a ready supply of books in the classroom, time given for reading, and the amount and breadth of reading. In situations where learners are required to bring a book from home, reading declines. All studies have shown positive links between the amount and frequency of reading, and comprehension, writing and language skills. The reading habit is acquired at an early age; many researchers have tried to identify conditions associated with children's predisposition to read finding that one of the most significant indicators of future reading is the "shared book experience" between children and caregivers; consequently a "critical focus has been to get books in children's hands" (Neuman 1999: 286). Children who live in deprived areas or homes, attend poorly resourced schools or live in remote areas are thus presented with a serious barrier to reaching their potential and achieving success at school. ${ }^{5}$ One way of encouraging the reading habit, suggested by many studies, is by increasing the "volume of children's playful, stimulating experiences with good books" (Neuman 1999: 289), pointing to the important relationship between the productive use of books in the classroom and quality of learning (Taylor, Muller \& Vinjevold 2003).

In an influential global study of comparative reading scores it was found that countries with high reading scores are those where learners have greater access to reading material at home, in the community, in libraries and at school (Elley 1992: xii). Research has identified the importance of exposing children to a variety of sources and allowing them to choose which leads to improved performance, and greater motivation and satisfaction (Clark and Phythian-Sence 2008: 3). Developing a print-rich environment is important from the child's early years and should not be neglected as children move through the higher grades.

Recent research on the development of reading and writing skills in young children is unequivocal; the young child must begin to gain literacy skills during the very early years to be academically successful. One way to begin to accomplish this is for the child to be immersed in a print rich environment. This environment must include an array of opportunities to see and respond to language in a context that is motivating and important to the child. This is particularly invaluable for students who come from homes without rich print opportunities (Scher 1999: 5).

4.2 Voluntary reading: reading for pleasure

There is a positive relationship between the amount of voluntary reading and academic performance (Elley 1992: xiii). Research from the Organisation for Economic Co-operation and Development (Organisation for Economic Cooperation and Development 2002) has shown that reading enjoyment is more important for children's educational success than their family's socio-economic status. Reading for pleasure (also known as voluntary reading) could therefore be one important way to help combat social exclusion and raise educational standards (Organisation for Economic Cooperation and Development 2002). It, (variously referred to as reading for enjoyment and voluntary reading),

... refers to reading that we to do of our own free will anticipating the satisfaction that we will get from the act of reading. It also refers to reading that having begun at someone else's request we continue because we are interested in it. It typically involves materials that reflect our own choice, at a time and place that suits us (Clark \& Rumbold 2006: 6).

The researcher Krashen (2004) has done a number of investigations into the role of free reading, or reading for pleasure. Overwhelmingly the evidence shows that those who do more recreational reading have superior reading, writing and comprehension skills in both mother tongue and second language subjects. The opportunities for playful interaction with books are opportunities for mastery of technical reading skills that are afforded by meaning-making, communication and creative expression (Bloch 2006: 13). Bloch points to the barrier to the development of reading literacy in primary schools in Africa as a consequence of the tyranny of the textbook, which relegates storybooks to supplementary and

5. Macfarlane has pointed out that in spite of rapid urbanisation, most South African pupils attend schools in rural areas (2005: 4) 
therefore non-essential and unimportant material (2007: 53). The best readers are those children who have positive attitudes to reading, and who read for pleasure (International Reading Association 2000).

4.3 Reading in the mother tongue

There is consensus that success in a second language is dependent on proficiency in the mother tongue (Abadzi 2006: $x$ ) - a fact of relevance for those children in South African schools whose mother tongue is not English. Equal status of all eleven official languages is afforded by law, and strengthened by the promulgation of the Language in Education Policy (LiEP) of 1997 which promotes 'additive approaches in bilingualism' at school. The effect of this is that it is assumed that once mother tongue has been firmly established, one or more languages are added (Bloch 2006: 25). Mother tongue education up to at least Grade 3 is expected by government, with the introduction of at least one other language in Grade R. In $2000,83 \%$ of learners were African language speakers, of which almost $70 \%$ were in exclusively African school environments (Heugh 2000: 22). Land (2003: 94) has noted the association in South Africa between an impoverished reading culture and the devaluing of indigenous languages associated with reluctance of publishers to publish in African languages.

\section{Research approach}

The objectives of this particular programme were to:

- Promote reading and the use of books in the classroom

- Promote voluntary reading by children.

The specific research objectives of the project were to assess the impact of the donation by assessing how and whether:

- The books were easily available to the children

- The children were reading the books

- The children were borrowing them to take home

- The teachers were including more book related activities in their daily programmes.

The participants in the study were drawn in equal numbers from each of the 20 participating schools:

- 10 randomly selected school children in Grade 4, with an average age of 12 years; a total of 200

- All Grade 4 teachers; a total of 20.

Trained fieldworkers fluent in the predominant home language in the different schools employed a variety of qualitative methods which were designed to yield comparative data collected over a span of six months representing the situation before and after the books were received:

- Observation

- Focus group: children, using graphic tools such as drawing, building up diagrams and pictures with cards

- Focus group interviews: teachers.

There were two site visits to each school. The initial visits allowed the collection of baseline data, important in being able to establish change and evidence of progress.

Since the study was conceptualised as an impact study we spent time considering what impact means and how to assess it, finding the model by Markless and Streatfield (2006: 50) very useful. The first stage of the model starts with a delineation of the objectives of the programme, which is followed by working out a couple of impact indicators. The indicators are derived by asking the question "How will we know if we are making a difference?"

The typology proposed by Markless and Streatfield (2006: 64) pointed us to the areas where we could look for evidence of change:

- Affective

- Behavioural

- Knowledge-based

- Competence-based

The indicators or success criteria which we derived from the objectives are displayed in Table 2.

SA Jnl Libs \& Info Sci 20II, 77(2) 
Table 2 Indicators of success

\begin{tabular}{|c|c|c|c|c|}
\hline Indicators & Affective & Behavioural & Knowledge & Competence \\
\hline Domain & Attitude & Action & Cognition & Skills \\
\hline Specific focus & $\begin{array}{l}\text { Value of reading } \\
\text { Confidence levels }\end{array}$ & $\begin{array}{l}\text { What do respondents do } \\
\text { differently, less or more } \\
\text { often? }\end{array}$ & $\begin{array}{l}\text { Understanding of narrative: } \\
\text { Children } \\
\text { Book knowledge: } \\
\text { Teachers }\end{array}$ & $\begin{array}{l}\text { Use of books: } \\
\text { Children } \\
\text { Teachers }\end{array}$ \\
\hline Respondents & Teachers/ children & Teachers/children & Teachers/children & Teachers/children \\
\hline Methods & $\begin{array}{l}\text { Questions } \\
\text { Observation }\end{array}$ & $\begin{array}{l}\text { Questions } \\
\text { Observation }\end{array}$ & $\begin{array}{l}\text { Questions } \\
\text { Observation }\end{array}$ & $\begin{array}{l}\text { Questions } \\
\text { Observation }\end{array}$ \\
\hline Data collection & First and second site visit & First and second site visit & First and second site visits & First and second site visits \\
\hline Examples & $\begin{array}{l}\text { What are the benefits of } \\
\text { reading? } \\
\text { What is teacher's attitude } \\
\text { to reading? }\end{array}$ & $\begin{array}{l}\text { Literacy events: } \\
\text { What is happening in the } \\
\text { classroom? } \\
\text { What is the teacher doing? } \\
\text { What are the children doing? }\end{array}$ & $\begin{array}{l}\text { Can children read? } \\
\text { Do teachers know how to } \\
\text { shelve and display books? } \\
\text { Can they manage the } \\
\text { circulation of books? }\end{array}$ & $\begin{array}{l}\text { Can children re-tell a story? } \\
\text { Can they talk about their favourite } \\
\text { book? } \\
\text { Can teacher incorporate books } \\
\text { into classroom activities? }\end{array}$ \\
\hline
\end{tabular}

\section{Findings}

We classified the findings into the following themes:

- Availability of books: print environment

- Literacy events

- Literacy discourse.

We used these categories, which emerged from our theoretical framework and which guided our questions, to compare data from the before and after visit in order to chart difference and change, and their direction. Each theme can be mapped to the matrix of indicators of success. Availability was investigated in terms of behaviour; literacy events encompassed all the dimensions: behavioural, attitudinal, knowledge and skills; and an analysis of literacy discourse revealed attitude.

6.1 Availability of books: print environment

Of the 20 schools, 7 were found at the first visit to have no classroom collection or library at all, thus the print environment was poor with no books available for the children to read either in the classroom or at home. At the second visit it was observed that five of the seven schools had still made no effort to provide a space for shelving and reading. Lack of space could not in these instances account for non-action, as even the most cramped of classrooms had been modified to create room for books in a number of schools. One of the children in one of these schools said: "You know why I like these books because when I'm free in class I just grab a book behind me ... you could sit in front of them and just read them all." However, the mere presence or absence of books does not translate into use and borrowing as we discovered; in one of the schools where the books were appropriately displayed in the classroom, the children were forbidden to touch them - a source of great frustration as the children expressed in the following typical comments:

"We are so happy that we have Biblionef books in our school even though we haven't read them but the outside cover does grab the attention";

"The way the books are packed, they look so easy to reach";

"If the teachers could let us touch the new books we know we could know lot of stories to tell more especially that they are in our classroom";

"So our main problem is that we are scared to borrow the books from the teacher and they don't make it easier for us in terms of borrowing"; and

"We steal the books when the teacher is out."

At the start of the project we found that the vast majority of schools - 16 schools - did not allow children to borrow books - either because there were no books, or as a matter of policy. The second site visit showed change in a positive direction in II schools, while five schools persisted with this prohibition. Thus we could deduce teachers' attitudes also from their behaviour that either encouraged or discouraged in their pupils to carry out extra-curricular reading, a factor influential in the amount of reading outside the classroom (Watkins \& Edwards 1992). 


\subsection{Literacy events}

We were interested in observing and recording literacy events at the schools, as a major purpose of the project had been to promote reading and use of books; thus we explored two related themes:

- Voluntary reading at school by children; and

- Use of books in the classroom and other venues by the teacher.

We also examined language preference.

Voluntary reading of books by children during school hours was a rare phenomenon during the first site visit, being observed at only one school. At the end of the project, voluntary reading was seen to be a regular occurrence at I5 schools, while in five no positive change was observed. Teachers recounted their experience of the increase in this activity by children:

"Children want more books to read";

"They want to read even during lunch time";

"When a teacher is absent instead of 'overplaying' they read their books";

"Always asking for books, and they read during break"; and

"They always want to go to the library, so now I have a library period".

Teachers at fifteen schools had introduced reading activities such as reading clubs, opportunities for the children to talk about their reading, writing of stories, reading competitions and debates. In five of these schools, reading was featured in the weekly assembly - with children participating in reading activities, or narrating stories they had read.

It was not possible to gauge from the findings the extent to which the children appreciated that the majority of books were in their mother tongue. In the focus groups, they spent more time talking about how the books were helping them with their English. The reading competitions were also in English. The prominence of English in all the schools is consistent with what other researchers have found, viz. the pressure to opt for the ex-colonial language (Bloch 2007: 50) associated with its economic power and prestige, manifested in teachers' preferences and parents' and children's demands.

\subsection{Literacy discourse}

We posed the same question to participants on the occasion of the donation and during the second visit to gauge their personal views of the benefits of reading, which would reveal attitudes and dispositions towards reading. At the start of the project the responses of both children and adults were overwhelmingly framed in utilitarian terms: the acquisition of knowledge, the development of skills related to reading and writing, the passing of examinations. The children's views echoed those of their teachers. This was common to all schools, and is reflected in the following typical quotations referring to the value of reading for them:

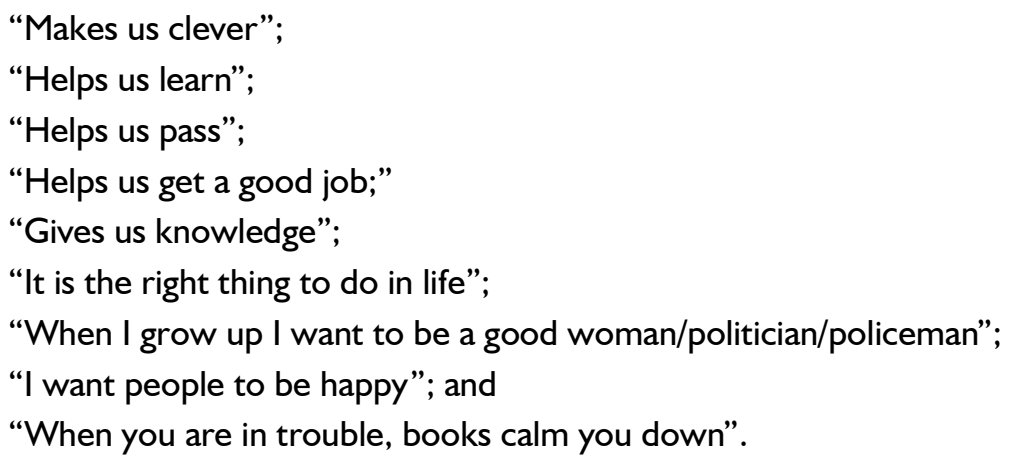

While a rise in the level of enjoyment, motivation to read, and interest in books was reported in most schools after the donation, teachers employed the same type of language as in the first visit, emphasising improvements in spelling, understanding of English and writing, comprehension, book handling. However, in four schools the teachers spoke about the dimensions of enjoyment, excitement, passion and engagement in describing the benefits they had observed of the increased opportunity for children to read.

After the donation, the children continued to echo their earlier motivation to read, but supplemented with greater specificity, e.g. knowledge about airplanes, learning about morals. A number made comments about the aesthetic appeal of the books, commenting approvingly on colourful covers, and the value of the "beautiful illustrations", a novelty for them. 


\subsection{Other effects}

The book donation had other - unanticipated but positive - consequences. In two schools the principals had been successful in securing funds to offer training to two people to take charge of the library. At one school a building contractor had offered to build a library, at another a child who had been heard to recite a poem was offered a bursary by a local doctor, and one school reported that children from surrounding schools, attracted by the news that its pupils were being allowed to take new books home, were applying for entrance.

\section{Conclusions}

In a field where much of the research trying to demonstrate impact of reading in primary schools relies on pre- and postcomprehension tests, we think that our qualitative methods can be developed to produce credible evidence of the impact of exposure to books in the primary school. We found positive change in all but five of the participating schools, but were unable to extract reasons for their inertia: why books were not unpacked, why they were in a storeroom, or why they could not be traced in the library where it was claimed they had been shelved. Teachers' refusal to allow pupils to look at or borrow books is not a rare phenomenon in South African schools, where many researchers have reported that book donations and school workbooks provided by departments of education remain in their cartons, stored in the principal's office, or relegated to a storeroom (Zinn 20I I; Bloch 2007: 54).

The increased incidence of the borrowing books that we observed provides opportunities for children and adults to read together and share the pleasure that this can bring, a significant factor in the promotion of reading. The introduction of reading activities during assembly is an important success indicator, as research has shown that literacy events are shaped by and can be interpreted through a cultural lens; in this instance a high status individual endorsing and promoting reading as a valued activity at functions with great symbolic importance. These events also demonstrate that at all these schools, at least some children had developed a sense of narrative - evidence of an improvement in their concept of print - which is an essential ingredient of the reading experience, and a prerequisite for increased frequency of reading.

There is much evidence in our study to document increased reading in most of the schools, encouraged through a variety of activities, and there is some progress in viewing reading as an enjoyable and discretionary activity, eroding the technicist approach embedded for so long that emphasises decoding of text from textbooks often devoid of context. This trend is in line with the emergent education policy that has started to adopt a "culture of reading" perspective, recognising that a radical departure from entrenched practice is required to improve reading levels at school (Bloch 2007: 50). The pointlessness of the strictly pedagogical method cannot develop reading skills and a love of reading in children who, exposed to its sterility, cannot imagine why anybody would find use and pleasure in reading (Bloch 2007: 50).

We attribute the positive changes that we documented in most schools to the training that accompanied the donation. This is an important learning for those involved in policy and planning for the improvement of literacy skills in our primary schools - that you cannot expect the teachers to work confidently with materials at their disposal without providing specialised training in the use of books, and some benign monitoring of its progress.

\section{Acknowledgement}

This research has been made possible by financial grants from the National Research Foundation (NRF) of South Africa and the South African Library and Information (SALI) Trust, South Africa. We are grateful for their support.

\section{References}

Abadzi, H. 2006. Efficient learning for the poor: insights from the frontier of cognitive neuroscience. Washington: The World Bank.

Barton, D. \& Hamilton, M. 2000. Literacy practices. In D. Barton, M. Hamilton, \& R. Ivanic (eds). Situated literacies: reading and writing in context. New York: Routledge, pp. 7-I5.

Bloch, C. 2006. Theory and strategy of early literacy in contemporary Africa with special reference to South Africa. PhD Summary Paper of a Cumulative Ph.D.Thesis presented to the Faculty of Education, Carl von Ossietzky Universität Oldenburg. [Online]. http://www.zsn.uni-oldenburg.de/download/CaroleBloch.pdf. (I June 20I I).

Bloch, C. 2007. Putting little books into little hands in the Year of African Languages: stories across Africa project initiative. In: $\mathrm{N}$. Alexander and B. Busch (eds). Literacy and linguistic diversity in a global perspective: an intercultural exchange with African countries. Strasbourg: Council of Europe Publishing, pp. 49-62.

Clark, C. \& Phythian-Sence, C. 2008. Interesting choice: the (relative) importance of choice and interest in reader engagement. London: National Literacy Trust

Clark, C. \& Rumbold, K. 2006. Reading for pleasure: a research overview. London: National Literacy Trust.

Comber, B. \& Cormack, P. 1997. Looking beyond 'skills' and 'processes': literacy as social and cultural practices in classrooms. Reading, 3I(3): 22-29.

Elley, R. 1992. How in the world do students read? Hamburg: The Hague International Association for the Evaluation of Educational Achievement.

Equal Education. 20I I. We can't afford not to: costing the provision of functional school libraries in South African public schools. $2^{\text {nd }}$ ed. Cape Town: Equal Education. 
Heath, S.B. 1987. Protean shapes in literacy events: ever-shifting oral and literate traditions. In D. Tannen (ed.) Spoken and written language: Exploring orality and literacy. Norwood, NJ: Ablex, pp. 9I-II 7.

Heugh, K. 2000. Multilingual voices - isolation and the crumbling of bridges. Agenda, 46: 21 -33.

Howie, S., Venter, E., Van Staden, S., Zimmerman, L., Long, C., Du Toit, C., Scherman, V. \& Archer, E. 2008. PIRLS 2006: Summary Report. South African Children's Reading Literacy Achievement. Pretoria: University of Pretoria. Centre for Evaluation and Assessment.

International Reading Association. 2000. Providing books and other print materials for classroom and school libraries. A Position Statement of the International Reading Association. [Online]. www.reading.org/downloads/positions/ps I 039_libraries.pdf. (I I July 20II).

Jansen, J. 20 I I. Fixing a class-based calamity. Sunday Times, 10 July 201 I: 15.

Krashen, S. 2004. Free voluntary reading: new research, applications and controversies. Unpublished paper presented at the RELC Conference, Singapore, September 2004. [Online]. http://www.sdkrashen.com/articles/pac5/all.html. (I I July 20 I I).

Land, S. 2003. The state of book development in South Africa. Journal of Education, 29: 93- 123.

The Library and Information Services Transformation Charter 2009. Commissioned by the Department of Arts and Culture (DAC) and National Council for Library and Information Services (NCLIS). $6^{\text {th }}$ Draft, July.

Macfarlane D. 2005. Treat rural schools as special case, report urges. Mail and Guardian. May 27- June 22005.

Mohlala, T. 20I I. Learning through reading. Mail and Guardian Online. [Online]. http://mg.co.za/article/20II-07-20-learningthrough-reading/. (22 July 20II).

Markless, S. \& Streatfield, D. 2006. Evaluating the impact of your library. London: Facet Publishing.

Motshekga, A. 20I I. Statement on the release of the Annual National Assessment Results for 20I I by Mrs Angie Motshekga Minister of Basic Education, Union Buildings, June 28 20ll. [Online]. http://www.info.gov.za/speech/ DynamicAction?pageid=46I\&sid=19525\&tid=36I06. (30 June 20I I).

Mullis, I., Martin, M., Kennedy, A., Trong, K. \& Sainsbury, M. 2009. PIRLS 20I I Assessment Framework. Amsterdam: International Association for the Evaluation of Educational Achievement (IEA). [Online]. http://timss.bc.edu/pirls20ll/downloads/ PIRLS20II Framework.pdf (I9 July 20II).

Neuman, S. 1999. Books make a difference: a study of access to literacy. Reading Research Quarterly, 34(3): 286-3I I.

Organisation for Economic Co-operation and Development. 2002. Reading for change. Paris: OECD.

Scher, S. 1999. Creating a print rich environment. Unpublished paper for Fredrick County Public Schools, USA. [Online]. fcpsteach.org/docs/Create\%20Print\%20Rich.pdf. (22 July 20I I).

South Africa, Department of Basic Education. 2010. Education for all. 2009 country report: South Africa. Pretoria: Department of Basic Education. [Online]. http://www.info.gov.za/. (30 June 20I I).

South Africa, Department of Education. 2008. The national reading strategy. Pretoria: Department of Education.

South African Partners. 2006. Libraries for South African schools. [Online]. http://www.sapartners.org/ index.php?option =com_content\&view $=$ article\&id $=28 \&$ Itemid $=25$. (I 3 July 20 I I $)$.

Taylor N., Muller, J. \& Vinjevold, P. 2003. Getting schools working. Cape Town: Maskew Miller Longman.

UNESCO (n.d). Online Statistics. [Online]. http://stats.uis.unesco.org/unesco/. (28 July 20I I).

Van der Berg, S., Burger, C., Burger, R., de Vos, M., Du Rand, G., Gustafsson, M., Moses, E., Shepherd, D., Spaull, N., Taylor, S., Van Broekhuizen, H. \& Von Fintel, D. 20I I. Low quality education as a poverty trap. Stellenbosch: University of Stellenbosch. Social Policy Research Group.

Watkins, M. \& Edwards, V. 1992. Extra-curricular reading and reading achievement: the rich stay rich and the poor don't read. Reading Improvement, Winter: 236-242.

Wray, D., Medwell, J., Poulson, L. \& Fox, R. 2002. Teaching literacy effectively in the primary school. London: Routledge.

Zinn, S. 20I I. Personal communication. 